\title{
New drugs for migraine
}

\author{
Lars Jacob Stovner · Erling Tronvik • \\ Knut Hagen
}

Received: 30 July 2009/Accepted: 1 September 2009/Published online: 1 October 2009

(C) Springer-Verlag 2009

\begin{abstract}
After the triptans, a calcitonin gene-related peptide blocker (telcagepant) is the first acute medicine that has been developed primarily for treatment of acute migraine. Otherwise, the new drugs have been developed first for other purposes, like anticonvulsants, antihypertensives and antidepressants used for migraine prophylaxis. For acute attacks, a new way to administer a traditional drug like dihydroergotamine is under way, and documentation of efficacy in migraine has been gained for some commonly used painkillers and anti-inflammatory drugs, and for some herbal extracts. Based on insights into the basic pathophysiological mechanisms of the disorder, some drugs have been developed which seem promising in early phase II studies (NOS inhibitors and 5HT1F-receptor agonists). In the future, development and enhancements of existing medicines must be accompanied by increased efforts to develop truly new migraine drugs based on knowledge of the pathophysiology if one wishes to reduce substantially the great burden migraine poses on patients and society.
\end{abstract}

Keywords Migraine - New drugs - Randomized trials · Review · Innovation

\footnotetext{
L. J. Stovner $(\bowtie) \cdot$ E. Tronvik $\cdot$ K. Hagen

Norwegian National Headache Centre,

Trondheim University Hospital, 7006 Trondheim, Norway

e-mail: lars.stovner@ntnu.no

L. J. Stovner · E. Tronvik · K. Hagen

Department of Neuroscience, Norwegian University

of Science and Technology, Trondheim, Norway

L. J. Stovner · E. Tronvik · K. Hagen

St. Olavs Hospital, Trondheim, Norway
}

\section{Introduction}

Migraine is the most prevalent and probably also the most costly of the neurological disorders [1], presumably affecting $11 \%$ of the population wordwide [2], but allocation of resources for treatment [3] and research [4] for migraine and headache in general is not proportional to the societal importance of these disorders. In spite of this, the last two to three decades have seen a large progress in knowledge about the complex biology of migraine. Although many new drugs are found by serendipity, some potent new medicines are now developed de novo for migraine primarily on the basis of insight into the pathophysiology. This includes both central and peripheral mechanisms, as well as nerves and vessels. During migraine attacks, there seems to be a gradual sensitization of neurons on different levels [5], first in the periphery, around vessels and meninges, and then in the CNS, most likely in the trigeminal nucleus caudalis (TNC). Much has been learned by studying the complex innervation of the cephalic vasculature by three different types of extrinsic nerves (sympathetic, parasympathetic and sensory trigeminal) and some important transmitters [most notably calcitonin gene related peptide (CGRP), and nitric oxide (NO)] [6]. The cerebral vasculature is influenced by intrinsic cerebral pathways, stemming from serotoninergic, adrenergic, cholinergic, glutaminergic and other brainstem centres [6]. Positron emission tomography studies have shown that brainstem structures are activated during migraine attacks [7], which broadly include the pain - modulating centres in the periaqueductal grey (PAG) and the nucleus raphe magnus (NRM) [7]. A common hypothesis is that the migraine pain results from a deficiency of 5-HT in the descending pain modulating system of the brain [8]. However, the typical migraine aura cannot be directly explained by brainstem events, but rather by cortical spreading depression (CSD) [9], 
Table 1 Randomized, double blind trials of topiramate for migraine prophylaxis

\begin{tabular}{|c|c|c|c|c|c|c|c|c|}
\hline Study & $\begin{array}{l}\text { Target } \\
\text { population }\end{array}$ & $\begin{array}{l}\text { Topiramate } \mathrm{N} \\
\text { (dropouts) }\end{array}$ & $\begin{array}{l}\text { Maintenance } \\
\text { period } \\
\text { (weeks) }\end{array}$ & $\begin{array}{l}\text { Mean } \\
\text { dosage/ } \\
\text { day }(\mathrm{mg})\end{array}$ & $\begin{array}{l}\text { Migraine frequency } \\
\text { (\% reduction from } \\
\text { baseline) }\end{array}$ & $\begin{array}{l}\text { Therapeutic gain } \\
\text { (\% reduction } \\
\text { vs.placebo) }\end{array}$ & $\begin{array}{l}\text { Responders } \\
\text { (Active \%/ } \\
\text { Placebo \%) }\end{array}$ & $\begin{array}{l}\text { Adverse } \\
\text { events } \\
(\%)\end{array}$ \\
\hline Storey [19] & $\mathrm{MoA}+\mathrm{MA}$ & $19(3)$ & 8 & 125 & 36 & 24 & $26 / 10$ & $>68$ \\
\hline Silvestrini [20] & Chronic migraine & $14(1)$ & 8 & 50 & 61 & 60 & $71 / 7$ & 36 \\
\hline \multirow[t]{3}{*}{ Brandes [21] } & \multirow[t]{3}{*}{$\mathrm{MoA}+\mathrm{MA}$} & $120(58)$ & 18 & 50 & 24 & 4 & $39 / 23$ & $>34$ \\
\hline & & $122(57)$ & & 100 & 40 & 20 & $49 / 23$ & $>50$ \\
\hline & & $121(47)$ & & 200 & 41 & 21 & $47 / 23$ & $>49$ \\
\hline \multirow[t]{2}{*}{ Diener [22] } & \multirow[t]{2}{*}{$\mathrm{MoA}+\mathrm{MA}$} & $139(45)$ & 18 & 100 & 44 & 24 & $37 / 22$ & $>77$ \\
\hline & & $143(78)$ & & 200 & 28 & 8 (NS) & $35 / 22$ & $>81$ \\
\hline \multirow[t]{3}{*}{ Silberstein [23] } & \multirow[t]{3}{*}{$\mathrm{MoA}+\mathrm{MA}$} & $117(49)$ & 18 & 50 & 24 & 6 (NS) & $36 / 23$ & $>36$ \\
\hline & & $125(42)$ & & 100 & 39 & 21 & $54 / 23$ & $>47$ \\
\hline & & $112(67)$ & & 200 & 41 & 23 & $52 / 23$ & $>47$ \\
\hline Silberstein [24] & $\mathrm{MoA}+\mathrm{MA}$ & $138(45)$ & 12 & 161 & 30 & 10 & $40 / 34$ & 90 \\
\hline Silberstein [25] & Chronic migraine & $153(73)$ & 12 & 86 & 37 & 9 & NA/NA & 83 \\
\hline Diener [142] & Chronic migraine & $32(8)$ & 12 & 100 & 23 & 24 & $22 / 0$ & 75 \\
\hline Keskinbora [27] & $\mathrm{MoA}+\mathrm{MA}$ & $20(4)$ & 4 & 43 & 90 & NA & NA/NA & 40 \\
\hline Ashtari [28] & $\mathrm{MoA}+\mathrm{MA}$ & $31(1)$ & 8 & 50 & 70 & NA & NA/NA & $>23$ \\
\hline Millan-Guerrero [29] & $\mathrm{MoA}+\mathrm{MA}$ & $45(10)$ & 12 & 100 & 46 & NA & $60 / \mathrm{NA}$ & $>47$ \\
\hline Dodick [30] & $\mathrm{MoA}+\mathrm{MA}$ & $172(70)$ & 22 & 91 & 41 & NA & $56 / \mathrm{NA}$ & 67 \\
\hline
\end{tabular}

$M A$ migraine with aura, $M o A$ migraine without aura

for which not only potassium ions and/or glutamate may play central roles, but also other ions and transmitters, including NO [10]. Migraine is clearly a genetic disorder, but the precise genetic basis for the most common forms is still unknown. In some cases of familial hemiplegic migraine, single locus mutations have been found in genes for either a brain-specific calcium channel (CACNA1A), an ATPdependent sodium pump (ATP1A2) or a voltage-gated sodium channel (SCNA1) [11]. It is believed that also common migraine forms are channelopathies, i.e. related to some functional derangement of ion channels.

The purpose of the present review is to look at the experience we have with the new drugs introduced in this century, and to give a glimpse of the exciting new possibilities for drug treatment that may emerge in the years to come. This means that the triptans, for which extensive reviews [12] and meta-analyses [13] have been written earlier, are mostly omitted, but some old drugs may be included if there has come new evidence for effect, or novel formulations that may present a meaningful advance. We have also discussed at some length drugs which ultimately have proven to be ineffective but which have become quite extensively used based on limited evidence.

\section{Anticonvulsants}

In the 1990 s, it became increasingly evident that valproate was effective for migraine prophylaxis [14], and after this many new antiepileptic drugs have been tested for migraine. A Cochrane report [15] on the use of anticonvulsants in migraine prophylaxis in adults concluded that this drug class reduced the frequency of attacks with 1-2 per month, and more than doubled the chance of having a reduction in attack frequency of more than $50 \%$ compared with placebo. Topiramate and valproate contributed most to the effect. Lamotrigine, clonazepam, vigabatrin and acetazolamide were not significantly different from placebo. A review of anticonvulsants for paediatric migraine [16] concluded that none of the drugs had adequate documentation of effect, and the paper called for new studies to establish safe and efficient migraine prophylactic drugs for children and youth. Several cerebral effects of the aniconvulsants may account for their effect in migraine, such as increase in the inhibitory transmitter GABA, antagonism of the excitatory transmitter glutamate, inhibition of sodium channels [17] and effects on calcium-channels in cortical and PAG neurons [18].

Topiramate (TPM) is probably the best documented migraine prophylactic drug in both episodic migraine (with and without aura) and in chronic migraine [19-30] (Table 1). Efficacy is well documented and placebo-subtracted reduction in migraine frequency (therapeutic gain) in most studies is around 20\%. Adverse events (e.g. paresthesias, dizziness, fatigue, weight loss, memory difficulties and language disturbances) are common, but data from several controlled trials [31] indicate that TPM is generally safe for use in adult migraineurs. Although the exact mechanism of action is not known, TPM has several 
pharmacological properties that may be relevant for its antimigraine effect [32-35], such as blockade of voltage-gated sodium channels, which limits neuronal hyperexcitablility, blockade of L-type calcium channels which modulates neurogenic dural vasodilation and CGRP-induced dilatation, potentiation of GABA-mediated neurotransmission and reduction of neuronal firing in the trigeminocervical complex, suppression of glutamatergic transmission through kainate and AMPA receptors, and inhibition of carbonic anhydrase and activation of potassium currents. The sum of these effects on neuronal hyperexcitability may inhibit cortical spreading depression, pain transmission in PAG and signalling through the trigeminal system $[35,36]$.

With regard to gabapentin, the evidence is still inconclusive [15]. Of three randomised, controlled, double-blind trials (RCDBT) on migraine, one small study demonstrated a significant improvement of migraine with 1,200 mg gabapentin [37], with only mild side effects (somnolence, dizziness, tremor fatigue and ataxia) and no drop-outs. Another multicenter study of 145 patients, giving up to $2,400 \mathrm{mg}$ for 12 weeks also showed a an effect, and also with tolerable side effects [38]. However, a third study found no effect of daily doses of 1,200 or 2,000 mg [39]. According to the Cochrane report, these studies suggest a beneficial effect, but since the two most relevant studies had methodological weaknesses it is concluded that the compound needs further evaluation. But the evidence at present is so promising that the drug may be tried in problematic migraine patients [15].

For lamotrigine, there is only one RCDBT from 1997 [40], and this study, with a high drop-out rate and change of dosing regimen during the study, failed to show superiority over placebo. Otherwise, the more recent studies are open [41, 42] or only a case report [43]. Overall, the Cochrane review concludes that the drug lacks proof of efficacy [15]. Another apparently ineffective drug is oxcarbazepine which was tried for migraine prophylaxis in a relatively large RCDBT with doses to at least $1,200 \mathrm{mg} /$ day [44]. Zonisamide, mostly used as add-on drug in patients with partial epilepsia, has only been tried in open studies for migraine prophylaxis [45-48], one of them in paediatric patients. All show impressive reduction in attack frequency, and tolerability is very good, although a few patients report dysphoria and concentration problems [45]. Also levetiracetam has been tested for migraine prophylaxis only in open studies, whereof two in children and adolescents $[49,50]$ and one in adults [51]. No serious side effects were observed, but some reported irritability and aggressiveness.

Tonabersat, which has anticonvulsive properties in experimental animal models, is a blocker of gap junctions, inhibits CSD [52] and neurogenic inflammation, and reduces NO concentrations during CSD [53]. It seems to have no contractile effect on isolated vessels or myocardium [54], but it inhibits trigeminally mediated parasympathetic reflexes on carotid vasculature [55]. A RCDBT [56] on glyceryl-trinitrate (GTN)-induced migraine attacks in migraine patients gave inconclusive results, but the study had to be terminated due to side effects, possibly from the interaction of GTN and the study drug. In another RCDBT of tonabersat $40 \mathrm{mg}$ there were no significant differences in any effect parameter, although numerically all parameters favoured the substance over placebo. There were no serious adverse effects, but nausea, dizziness, and headache occurred more often in the tonabersat group [57]. In one recent RCDBT of 39 patients suffering from migraine with aura (both with and without headache, and including hemiplegic and basilar migraine), there was a significant effect of tonabersat $40 \mathrm{mg}$ only on the aura attacks and aura attacks followed by headache, but not on migraine attacks without aura or headache in general [58]. If larger studies confirm this finding, tonabersat may be the first drug with a selective effect on migraine with aura.

\section{Antihypertensive medication}

Beta-blockers have been a mainstay in migraine prevention in most countries, but few new drugs in this group have been investigated for migraine during the last decade. One small RCDBT compared one for migraine established betablocker, metoprolol $142.5 \mathrm{mg}$, with $5 \mathrm{mg}$ nebivolol, which is a third-generation beta-blocker with high $\beta-1$ selectivity, high lipid solubility to pass the blood-brain barrier, with little intrinsic activity and also a vasodilatory effect mediated by stimulation of endothelial NO production [59]. Both drugs gave a similar reduction of migraine attack frequency, but nebivolol had significantly fewer side effects [60].

The first RCDBT of a drug influencing the renin-angiotensin system (RAS) as migraine prophylactic was published in 2001, when lisinopril, an angiotensin-converting enzyme inhibitor (ACEI) [61] was shown to have a beneficial effect in a cross-over study. In 2003, a similar study demonstrated effect of candesartan, an angiotensin II, 1a-receptor blocker (ARB) [62]. Recently, an RCDBT on another ARB (telmisartan) showed effect on level with many other migraine prophylactics, but the study was inconclusive due to low power for a parallel group study [63]. The favourable side effect profile has made particularly candesartan an attractive alternative which has gained popularity in many countries in spite of the limited documentation of effect (see, e.g. [64]). For the ACEIs, coughing as a side effect may limit the use. Additional proof of efficacy of these classes of drugs in migraine is by open studies for ACEIs [65-67] and by a study on migraine among hypertensive patients for candesartan [68]. Also, there is circumstantial evidence that the effect of candesartan may be a class effect of the ARBs since a large pharmacoepidemiologic study showed decreased use of 
triptans when patients started using an ACEI or an ARB of any type [69], and a meta-analysis of RCTs with ARBs used for other indications showed that headache as a side effect was lower in the ARB group than in the placebo group, irrespective of the type of ARB [70]. The mechanism for the antimigrainous action of these drugs is not known, but it is most certainly not related to decrease in the blood pressure. Interestingly, there is an intrinsic RAS of the brain within the blood brain barrier [71], and in the trigeminal ganglion [72], which has many effects that may be relevant for migraine.

\section{Antidepressants}

Considering the reasonably good evidence for the tricyclic antidepressant amitriptyline as a migraine prophylactic [73] it is notable that a Cochrane review concluded that the selective serotonin reuptake inhibitors (SSRIs) are not effective in migraine or tension-type headache [74]. There are, however, some studies that indicate preventive effect of antidepressants that inhibit reuptake of both serotonin and nor-adrenalin. A RCDBT on 60 migraine patients with venlafaxine extended release tablets showed effect of both 75 and $150 \mathrm{mg}$ doses [75]. Adverse events occurred mostly on the highest dose, and they abated with time. An openlabel retrospective chart review of 65 migraine patients who used duloxetine showed a modest decrease in migraine frequency after 2 months, the decrease being most marked in the subgroup with anxiety [76].

\section{Drugs influencing the dopaminergic system}

Nausea, often a disabling migraine symptom, is relieved by antiemetics like metoclopramide or domperidone which are dopamine 2 (D2) receptor antagonists. These drugs are useful not only as antiemetics but they may probably also have some effect against the migraine [77]. Dopamine receptor blockers have received relatively little attention as regular anti-migraine drugs, most likely because of the side effects, but they may be useful for the particularly severe attacks seen in patients admitted to hospital for their migraines, where the first-line medications have failed. A RCDBT of 40 patients coming to the hospital emergency room demonstrated effect of i.v. infusion of $5 \mathrm{mg}$ of haloperidol, most patients being pain free within $1 \mathrm{~h}$ [78]. Side effects were common and included motor agitation and sedation. Another similar study of 68 patients [79] showed that chlorpromazine $0.1 \mathrm{mg} / \mathrm{kg}$ intravenously had effect after $1 \mathrm{~h}$ on headache and associated symptoms, the side effects being postural hypotension and drowsiness. Intramuscular droperidol, a dopamine antagonist used for induction of general anaesthesia, was tested in a RCDBT for acute migraine attacks in 305 patients [80]. There was effect with regard to headache relief at $2 \mathrm{~h}$ for doses 2.5 $8.25 \mathrm{mg}$. Asthenia, somnolence, anxiety and acathisia were side effects related to the study drug.

One drug in this class, olanzapine, an atypical dopamine blocker with relatively low tendency to induce extrapyramidal side effects, has been explored as a potential migraine prophylactic in a retrospective study of 50 migraine patients who had used the drug, usually 5-10 mg per day [81]. Patients had a significant decrease in headache days and headache severity, but side effects, weight gain and somnolence, were bothersome.

\section{CGRP receptor blockers}

CGRP is released from trigeminal sensory neurons, and its significance for migraine was suggested in 1990 when it was shown to be increased in blood sampled from the jugular vein during ongoing headache attacks [82]. Some but not all later studies have confirmed this [83]. A further indication is that infusion of CGRP can induce attacks in migraine patients [84]. In addition to being a potent vasodilatator it has a number of other effects, like release of histamine from mast cells and increased NO production in ganglion cells [85]. CGRP receptors are present not only in vessel walls, but also in the central nervous system (cerebellum, PAG and TNC).

The proof of concept study for CGRP receptor blockade in migraine was published in 2004 [86] with olcagepant which had to be given intravenously. Later studies have been done with the orally administered telcagepant [87, 88]. CGRP receptor blockers inhibit CGRP- induced vasodilatation, but under normal circumstances they seem to have no effect on cardiovascular parameters, and particularly not on coronary arteries, and they may therefore be used in migraine patients with coronary disease. Table 2 shows some of the data from the RCDBTs comparing telcagepant with either rizatriptan $10 \mathrm{mg}$ [88] or zolmitriptan $5 \mathrm{mg}$ [87], and it also gives data on the different triptans from a metaanalysis [13]. There is no dose-response relationship for the doses 300-600 mg, and the response rate is not consistently higher than that of the triptans, but the number of side effects seems somewhat lower. Since the mode of action differs fundamentally from that of the triptans, it is hoped that the drug will be a valuable addition to the armamentarium of acute migraine drugs, and particularly for the large group of patients who are not satisfied with triptans due to limited efficacy, side effects or contraindications. Recently, according to the medical trials, database ClinTrials.gov (Identifier: NCT00797667) a prophylactic study with telcagepant has been terminated because of two patients with significant elevations in serum transaminases, signifying 
Table 2 Efficacy and adverse events of telgacepant and triptans

\begin{tabular}{|c|c|c|c|c|c|c|}
\hline Study & Type of drug & $\begin{array}{l}\text { Pain relief } \\
\text { at } 2 \mathrm{~h}(\%)\end{array}$ & $\begin{array}{l}\text { Pain free } \\
\text { at } 2 \mathrm{~h}(\%)\end{array}$ & $\begin{array}{l}2-24 \text { h sustained } \\
\text { pain freedom }(\%)\end{array}$ & $\begin{array}{l}\text { Placebo-substracted } \\
\text { AE }(\%)\end{array}$ & $\begin{array}{l}\text { Adverse } \\
\text { events }(\%)\end{array}$ \\
\hline \multirow[t]{5}{*}{ Ho et al. [88]* } & Telcagepant $300 \mathrm{mg}$ & 68.1 & 45.2 & 32.0 & & 35.3 \\
\hline & Telcagepant $400 \mathrm{mg}$ & 48.2 & 24.3 & 22.0 & & 36.5 \\
\hline & Telcagepant $600 \mathrm{mg}$ & 67.5 & 32.1 & 39.6 & & 40.8 \\
\hline & Telcagepant $10 \mathrm{mg}$ & 69.5 & 33.4 & 18.4 & & 42.0 \\
\hline & Placebo & 46.3 & 14.3 & 11.0 & & 36.2 \\
\hline \multirow[t]{4}{*}{ Ho et al. [87] } & Telcagepant $150 \mathrm{mg}$ & 49.8 & 17.2 & 10.7 & & 31 \\
\hline & Telcagepant $300 \mathrm{mg}$ & 55.0 & 26.9 & 20.2 .4 & & 37 \\
\hline & Zolmitriptan $5 \mathrm{mg}$ & 56.4 & 31.3 & 18.2 & & 51 \\
\hline & Placebo & 27.7 & 9.6 & 5.0 & & 32 \\
\hline \multirow[t]{5}{*}{ Meta-analyses 2002} & Sumatriptan $100 \mathrm{mg}$ & $59(57-60)$ & $29(27-30)$ & & $13(8-18)$ & \\
\hline & Almogran $12.5 \mathrm{mg}$ & 58 & & & & \\
\hline & Rizatriptan $10 \mathrm{mg}$ & Ca. 70 & 37 & & & \\
\hline & Elitriptan $20 \mathrm{mg}$ & Ca. 68 & Ca. 40 & & & \\
\hline & Zolmitriptan $5 \mathrm{mg}$ & $>60$ & $42(36-48)$ & & & \\
\hline
\end{tabular}

* Only the highest doses are reported here

liver toxicity. The fate of telcagepant is therefore somewhat uncertain at the moment. Definitely, its greatest potential seems to be as acute migraine medication, and whereas liver toxicity is not expected with intermittent use, it is a common experience with most acute migraine medications that a small percent of patients will use them almost daily.

Although it is unlikely that telcagepant will be investigated for migraine prevention, there may be other ways to diminish the effect of CGRP than by receptor blockade. Currently, substances that reduce the circulating CGRP levels by acting as CGRP scavengers (antibodies and so called Spiegelmers) are under development, and these may in the future offer new possibilities of prophylactic treatment [89].

Somatostatin has been found to inhibit CGRP release, and the transmitter is also found in TNC and PAG. A somatostatin-analogue, octreotide, was tried subcutaneously in a RCDBT for migraine attacks, but with negative results [90].

\section{Nitrogen oxide inhibitors}

Intravenous infusions of the NO donor glyceryl trinitrate (GTN) tends to induce headache in all individuals, but more often in migraineurs who also get a migraine-like headache after a first phase with headache of more indeterminate nature [91]. Interestingly, NO does not seem to induce aura among patients with this migraine form, only the pain. NO is produced by degradation of L-arginin by NO synthetase (NOS) which exists in three different forms, endothelial, inducible and neuronal NOS (eNOS, iNOS and nNOS). Vascular effects of nNOS are mediated through parasympathetic fibres of the facial nerve to cephalic vessels where it mostly dilates arteries and veins but not arterioles which regulate tissue perfusion. nNOS and eNOS may both be involved in sensitisation of peripheral nerves and also central pain pathways. In view of its potentially important role in migraine, surprisingly few therapeutic studies have been performed with NOS-inhibitors. One small study with an NOS inhibitor given intravenously showed a response rate of $67 \%$ among 15 patients, in comparison to $14 \%$ among 15 patients who received placebo [92]. The study was blinded, but only 2 placebo patients were included in the study; the 14 others were historical placebo controls from another study. 3 of the 15 patients experienced some subjective side effects (pressure over the nose, tingling at the elbows and cold hands). Mean arterial pressure increased and heart rate decreased.

Hydroxocobalamin (OH-B12) is an NO scavenger, and in an open study, this compound given nasally for 3 months reduced the migraine frequency compared to the baseline period [93].

\section{Selective $5-\mathrm{HT}_{1 \mathrm{D}}$ and $5 \mathrm{HT}_{1 \mathrm{~F}}$-receptor agonists}

Triptans act on 5-HT $1 \mathrm{~B}$ and 5-HT $1 \mathrm{D}^{-}$-receptors, and some also on 5 - $\mathrm{HT}_{1 \mathrm{~F}}$-receptors. 5 - $\mathrm{HT}_{1 \mathrm{~B}}$-receptors mediate vasoconstriction, whereas the $5-\mathrm{HT}_{1 \mathrm{D}}$-receptors are believed to be involved in neurogenic inflammation of the dura. The selective $5-\mathrm{HT}_{1 \mathrm{D}}$-receptor agonist PNU-142633 has been shown to block plasma extravasation induced by stimulation of the trigeminal ganglion in rodents [94]. In a small RCDBT in migraine patients there was no effect on acute attacks [95]. 
A selective $5-\mathrm{HT}_{1 \mathrm{~F}}$-receptor- agonist (LY334370) has been tested in a small RCDBT with three different doses [96]. The two highest doses were clearly superior to placebo. Side effects were dizziness, somnolence, asthenia and paresthesia. This drug may act by blocking neurogenic inflammation or by blocking nociceptive information in the TNC. The 5-HT $\mathrm{HF}_{1 \mathrm{~F}}$-receptor- agonists seem to have no vasoconstrictor effect in the doses tried for migraine, and they may thus be safe for patients with vascular disorders [97].

\section{Dihydroergotamine delivered by inhalation}

In many countries, use of ergotamines decreased markedly when triptans were introduced, mainly due to side effects and safety concerns. However, quite recently the case has been made for a larger role for dihydroergotamine, due to its fast onset of action, relative safety and effect in particularly severe and long-lasting attacks [98]. This semisynthetic alkaloid has effects on a both adrenergic ( $\alpha$ and $\beta$ ), dopaminergic and serotoninergic receptors, the latter including 5-HT $1 \mathrm{~B}$ and 5-HT $1 \mathrm{D}$. Possibly, renewed interest in this compound may be awakened by the introduction of a new device for delivering the drug by inhalation, permitting uptake through the vast and very thin barrier in the lungs. This unusual way of delivering migraine drugs has been shown to be well tolerated, with excellent pharmacokinetics on level with intravenous administration [99], and safe even in patients with asthma [100]. A recent RCDBT has shown that inhalation of dihydroergotamine mesylate gave pain relief after $2 \mathrm{~h}$ in $72 \%$ of patients, which is higher than most oral or intranasal triptans, and with few side effects [101], and there was a rapid onset of action, with significant relief already after $10 \mathrm{~min}$. No additional effect but more side effects (mainly aftertaste) was seen for a higher dose of $1 \mathrm{mg}$.

\section{Glutamate receptor blockers}

The excitatory amino acid glutamate is believed to play an important role in CSD. In a small open study, ketamine, an antagonist of glutamate receptors of the NMDA subtype, reproducibly reduced aura symptoms with intranasal administration of the drug, but there was no effect on the headache [102]. Another drug (LY293558) is an antagonist of kainat and AMPA glutamate receptors. In a small RCDBT comparing the drug both with sumatriptan injections and placebo, LY293558 given intravenously was effective with regard to pain and accompanying symptoms of migraine [103]. The effect was somewhat smaller than with sumatriptan injections, but side effects were fewer.

\section{Capsaicin receptor blockers}

Antagonists against "capsaicin receptors", usually referred to as transient receptor potential vanilloid subfamily, member 1 (TRPV1), are currently under investigation for migraine. This receptor type is sensitive to capsaicin, which gives the burning taste of chilli peppers, and it is involved in processes causing thermal hypersensitivity. The fact that it is expressed in both central and peripheral trigeminal neurons and seems to be involved in neurogenic inflammation and sensitization makes it an interesting target for antimigraine drugs [104]. However, a series of trials of one TRPV1 antagonist, civamide, as acute migraine treatment has given disappointing results, and the trials have been terminated [105].

\section{Drugs influencing the prostanoid system}

Drugs for migraine exerting their effect through this system include acetyl salicylic acid and all the NSAIDs, which are among the most commonly used drugs for migraine. All these drugs inhibit cyclo-oxygenase (COX) which catalyses the conversion of arachidonic acid to prostaglandin $\mathrm{H}_{2}$, a precursor of the prostanoids which are important mediators of inflammatory reactions, but which also mediate a host of other functions. COX exists in at least two forms, COX 1 which is a constitutive enzyme found in most cells, and COX 2 which is an inducible enzyme involved in inflammatory reactions found in macrophages and other cells involved in inflammation. The classical NSAIDS inhibit both COX 1 and COX 2 alike, and the gastrointestinal side effects (most notably peptic ulcer) are related to COX 1 inhibition. The selective COX 2 inhibitors seem to cause less of these side effects, but this advantage is offset by increase in cardiovascular risk, probably by lowering vascular prostacyclin production without altering platelet thromboxane levels [106].

One large RCDBT [107] has shown effect of two different doses of the COX 2 inhibitor rofecoxib 25 and $50 \mathrm{mg}$ for a single migraine attack. Adverse effects were generally mild or moderate, but more common with the highest dose. Another large RCDBT has compared two doses of valdecoxib (20 and $40 \mathrm{mg}$ ) with placebo and sumatriptan $50 \mathrm{mg}$ doses. This showed that valdecoxib was better than placebo and similar to sumatriptan, but with fewer side effects [108]. A small open-label study [109], comparing the effect of yet another COX 2 inhibitor, celecoxib $400 \mathrm{mg}$, with that of a classic NSAID (Naproxen $550 \mathrm{mg}$ ) for a single migraine attack, found similar efficacy for the two drugs, but significantly fewer in the celecoxib group reported epigastric pain. 
Diclophenac has long been shown to have an effect on migraine attacks. Recently, a new formulation with higher water solubility (diclophenac DHEP) has demonstrated effect over placebo, and in lower doses than diclophenac potassium [110]. Another study tested diclophenac $100 \mathrm{mg}$ softgel with or without caffeine $100 \mathrm{mg}$ versus placebo in a triple cross over study in 46 subjects [111]. Only diclophenac + caffeine showed superiority over placebo at $60 \mathrm{~min}$.

Prostaglandin $\mathrm{E}_{2}$-receptor blockers are now under investigation for migraine. The EP4-receptor [112], which mediates some of the effect of prostaglandin E2 $\left(\mathrm{PGE}_{2}\right)$, is present in sensory dorsal root ganglia cells. $\mathrm{PGE}_{2}$, an inflammatory mediator, is also a neuromodulator that may alter neuronal excitability and synaptic transmission [113]. The blocker BGC20-1531 can antagonise PGE $_{2}$-induced dilatation of cranial arteries, but has no effect on coronary, pulmonary and renal arteries in vitro [112]. Still, proof of concept studies are lacking for the blocker. Another blocker, CJ-023,423, has been shown to reduce thermal and mechanical hyperalgesia in animal models, and is also effective in controlling inflammatory pain [114].

\section{Corticosteroids}

These drugs are often mentioned for treating status migrainosus, but the scientific documentation has been poor [115]. A recent Cochrane review [116] identified seven randomised, placebo-controlled studies of sufficient quality, whereof five were published in 2006 or later, on its use in severe migraine in an emergency department setting [117]. All used "standard abortive therapy" and then placebo or dexamethasone intravenously or intramuscularly, in doses from 10 to $24 \mathrm{mg}$ as an adjunct, with follow-up varying between 1 and 3 days. Overall, for all studies $(n=738)$ the risk of recurrence was significantly reduced by $26 \%$ in those receiving dexamethasone, with side effects similar to those in the placebo-treated group. As for oral dexamthasone, the effect of adding dexamethason $8 \mathrm{mg}$ to acute treatment with phenothiazines was not significant [118], although the absolute risk reduction was $12 \%$ in the steroid treated group.

\section{Paracetamol}

For a highly prevalent disease like migraine most patients from time to time treat their attacks by over the counter medication (OTC), and the main information they get about their medication is from the package label [119]. For this reason, it is important that adequate documentation on the effect for migraine exists. One RCDBT of acetaminophen (paracetamol) 1,000 $\mathrm{mg}$ as attack medication documented a significant effect over placebo and there was no difference with regard to side effects [119].

\section{Herbal extracts}

As with paracetamol, the fact that many patients treat their attacks with herbal medicines has been the motivation for testing the effect of the herbs feverfew (Tanacetum parthenium) and butterbur (Petastes hybridus) which have been widely used in traditional medicine. Feverfew is known to inhibit prostaglandin production and secretion of serotonin, and to influence contractility of cephalic vessels. In a recent RCDBT on the prophylactic effect of an extract given three times daily for 3 months, it was shown to be effective with regard to frequency of attacks, with side effects on level with placebo [120]. Butterbur, which has anti-inflammatory properties, has been investigated for prophylaxis in two RCDBTs, and both have suggested a treatment effect $[121,122]$ with mild side effects.

\section{Botulinum toxin}

Based on the knowledge about episodic migraine pathophysiology it would seem unlikely that a substance like botulinim toxin (BTX) which blocks the release of acetylcholin in the periphery on muscle cells and sweat glands should be helpful. In pain states where BTX is effective, it seems to reduce muscle spasms causing the pain, and there is good evidence that BTX has no intrinsic antinociceptive effect in experiments on human volunteers (for review see [123]). Generally, it may be difficult to determine its effect on headaches due to the possibility of unblinding because of the visible effect on the scalp muscles and its high placebo response [123]. In spite of this, many studies have been performed in both migraine and other headache conditions. As can be seen from the overview of the six RCTs [124-129] of botulinum toxin A in Table 3, the effect on migraine is not convincing. In general, adverse events in these studies are few and not serious, mostly ptosis and diplopia in a few patients [124, 125], and usually with the highest doses. In 2006, it was, based on the negative evidence published till then, concluded that BTX as prophylactic for episodic migraine and tension-type headache had come to the end of the road [130]. A similar opinion was expressed in a more recent review since none of the six controlled studies in migraine had shown any significant effect, and three of these studies were assessed as class I evidence [131]. Also, a recent report for the American Academy of Neurology has concluded that it is ineffective for episodic migraine [132]. In the debate following the latter report [133], critics objected that this view was based on admittedly well-conducted studies 
Table 3 Randomized placebo-controlled, double blind trials of botulinum toxin A for migraine prophylaxis

\begin{tabular}{|c|c|c|c|c|}
\hline Study & $N$ & Dose and application & & Result \\
\hline Silberstein [124] & 122 & 25 and $75 \mathrm{U}$, forehead and temples & Fixed sites & $\begin{array}{l}25 \mathrm{U} \text { showed better effect than } \\
\text { placebo, not } 75 \mathrm{U} \text { group }\end{array}$ \\
\hline Evers [125] & 60 & $16 \mathrm{U}$ in forehead, $100 \mathrm{U}$ in forehead and neck & Fixed sites & No difference between groups \\
\hline Elkind [127] & 418 & 25 and $50 \mathrm{U}$ in front and sides of head & Fixed sites & No difference between groups \\
\hline Aurora [126] & 369 & $110-260 \mathrm{U}$ & "Follow the pain" & No difference between groups \\
\hline Relja [128] & 495 & $75,150,225 \mathrm{U}$ in various head and neck muscles & Fixed sites & No difference between groups \\
\hline Cady [129] & 61 & $139 \mathrm{U}$, in various head and neck muscles & Fixed sites & $\begin{array}{l}\text { No significant differences in } \\
\text { headache frequency, but with } \\
\text { regard to headache impact } \\
\text { measure }\end{array}$ \\
\hline
\end{tabular}

but these used inadequate doses. In answer to this, the authors of the report stated that evidence-based reviews necessarily will be limited to the well-performed trials and cannot reflect all variations in dosages and injection techniques used among clinicians. Hence, it is always possible that future studies with refined techniques and measurements may yield different results, but up till now there is no good evidence to support the use of BTX in migraine.

\section{Combination drugs}

When triptans were introduced, monotherapy with these drugs supplanted in many countries the use of earlier combination pills of ergot, caffeine, tranquillizers or antiemetics. It was claimed that polypharmacy was partly responsible for side effects and medication overuse. However, it is obvious that the complex migraine pathophysiology offers multiple targets for pharmacological intervention, and today it is argued that drug combinations could give additional effects compared to monotherapy.

A large RCDBT of the combination of sumatriptan $50 \mathrm{mg}$ capsules and naproxen $500 \mathrm{mg}$ tablets against monotherapy of these same drugs [134] showed that the combination was superior to monotherapy. This was largely confirmed in two large RCDBTs, including almost 3,000 migraine patients, which compared the effect of a combination drug of sumatriptan $85 \mathrm{mg}$ and naproxen $500 \mathrm{mg}$ in one tablet, with monotherapy of the same drugs and doses, and with placebo [135]. An open-label safety study on 565 patients treating more than 24,000 attacks during a year showed that this combination drug was well tolerated [136]. Patients had typical triptan side effects, but few gastrointestinal problems, and there was only one serious cardiovascular event.

A RCDBT showed superiority of IndoProCaf, a combination drug given as suppositories containing prochlorperazine (a dopamine D2 receptor antagonist) $4 \mathrm{mg}$, indomethacin $25 \mathrm{mg}$ and caffeine $75 \mathrm{mg}$, over sumatriptan $25 \mathrm{mg}$ suppositories [137]. The number of adverse events was low and similar with the two treatments. Another RCDBT with Indoprocaf tablets (effervescent and coated) [138], with a lower prochlorperazine dose $(2 \mathrm{mg})$ than the suppositories, showed similar results as with sumatriptan $50 \mathrm{mg}$ tablets, with effervescent tablets being superior to coated ones.

One RCDBT compared sumatriptan $50 \mathrm{mg}$ with a combination drug containing acetaminophen $500 \mathrm{mg}$, acetylsalicylic acid $500 \mathrm{mg}$ and caffeine $130 \mathrm{mg}$ in a RCDBT including 170 patients [139] who were advised to treat their migraine early. The combination was better than sumatriptan after both 2 and $4 \mathrm{~h}$.

A RCDBT of tramadol $75 \mathrm{mg}$ in combination with acetaminophen $650 \mathrm{mg}$ for acute migraine attacks showed that the combination was superior to placebo for pain from 0.5 to $6 \mathrm{~h}[140]$.

As preventive treatment, a small RCDBT tested a combination of magnesium $300 \mathrm{mg}$ with riboflavin $400 \mathrm{mg}$ and feverfew $100 \mathrm{mg}$, but the combination did not show superior effect over placebo. However, since riboflavin changes the colour of the urine, the placebo had to contain $25 \mathrm{mg}$ riboflavin to obtain proper blinding [141]. In that study, the placebo effect was particularly high, and it is therefore possible that the negative result was due to an active effect of the placebo.

\section{Conclusion}

The past decade has seen relatively few new medicines for migraine, and after the triptans were introduced in the 1990s, the CGRP blocker is the only drug which may soon be ready for the market and which is a truly innovative drug developed primarily for migraine, based on knowledge of the pathophysiology of the disease. Otherwise, new migraine drugs are mostly medicines that have been designed for other diseases, most notably some anticonvulsants (topiramate) and antihypertensives (ACEIs, ARBS, third generation betablockers). We have also obtained documentation of efficacy in migraine for some well-known painkillers and anti- 
inflammatory medicines (parecetamol, NSAIDS and COX-2 inhibitors) which many patients use anyway, and the same goes for some herbal extracts. Likewise, corticosteroids and some dopamine agonists have proven their usefulness for the very severe attacks encountered in the hospital emergency room. We also see a movement towards more polypharmacy with combinations of well-known drugs. While all these developments undoubtedly represent progress, it is somewhat disquieting that development of some truly innovative substances, like NOS inhibitors and 5-HT $1 \mathrm{~F}$ blockers, which have been very promising in early phase II studies, seem to have come to a halt. It is natural that low-hanging fruits are picked first, but in the long run, development and enhancement of existing drugs may be an insufficient strategy if the goal is to obtain substantial improvements for migraine patients. It is reasonable to believe that the basic science of migraine has reached such maturity that more new drugs can now be developed primarily for migraine. This can only be achieved by a focussed and concerted research effort by academia and the pharmaceutical industry. While it is considerably more expensive to manufacture a drug de novo, new effective medicines for migraine will almost certainly give payback to the developer, produce large savings for society and reduced suffering for patients.

Conflict of interest None.

\section{References}

1. Andlin-Sobocki P, Jönsson B, Wittchen HU, Olesen J (2005) Cost of disorders of the brain in Europe. Eur J Neurol 12:1-27

2. Stovner L, Hagen K, Jensen R, Katsarava Z, Lipton R, Scher A, Steiner T, Zwart JA (2007) The global burden of headache: a documentation of headache prevalence and disability worldwide. Cephalalgia 27:193-210

3. Steiner TJ (2005) Lifting the burden: the global campaign to reduce the burden of headache worldwide. J Headache Pain 6:373-377

4. Olesen J, Lekander I, Andlin-Sobocki P, Jonsson B (2007) Funding of headache research in Europe. Cephalalgia 27:995-999

5. Burstein R (2001) Deconstructing migraine headache into peripheral and central sensitization. Pain 89:107-110

6. Hamel E (2006) Perivascular nerves and the regulation of cerebrovascular tone. J Appl Physiol 100:1059-1064

7. Weiller C, May A, Limmroth V, Juptner M, Kaube H, Schayck RV, Coenen HH, Diener HC (1995) Brain stem activation in spontaneous human migraine attacks. Nat Med 1:658-660

8. Panconesi A (2008) Serotonin and migraine: a reconsideration of the central theory. J Headache Pain 9:267-276

9. Schwedt TJ, Dodick DW (2009) Advanced neuroimaging of migraine. Lancet Neurol 8:560-568

10. Lauritzen M, Kraig RP (2005) Spreading depression. In: The headaches, 3rd edn. In: Olesen JG, Ramadan PJ, Tfelt-Hansen NM, Welch P (eds) K M A. Williams \& Wilkins, Lippincott, pp 269-274

11. van den Maagdenberg AM, Haan J, Terwindt GM, Ferrari MD (2007) Migraine: gene mutations and functional consequences. Curr Opin Neurol 20:299-305
12. Dahlöf C (2002) Integrating the triptans into clinical practice. Curr Opin Neurol 15:317-322

13. Ferrari MD, Goadsby PJ, Roon KI, Lipton RB (2002) Triptans (serotonin, 5-HT1B/1D agonists) in migraine: detailed results and methods of a meta-analysis of 53 trials. Cephalalgia 22:633-658

14. Mathew NT (2001) Antiepileptic drugs in migraine prevention. Headache 41(Suppl 1):S18-S24

15. Mulleners WM, Chronicle EP (2008) Anticonvulsants in migraine prophylaxis: a Cochrane review. Cephalalgia 28:585-597

16. Bakola E, Skapinakis P, Tzoufi M, Damigos D, Mavreas V (2008) Anticonvulsant drugs for pediatric migraine prevention: an evidence-based review. Eur J Pain

17. Casucci G, Villani V, Frediani F (2008) Central mechanism of action of antimigraine prophylactic drugs. Neurol Sci 29(Suppl 1):S123-S126

18. Martella G, Costa C, Pisani A, Cupini LM, Bernardi G, Calabresi P (2008) Antiepileptic drugs on calcium currents recorded from cortical and PAG neurons: therapeutic implications for migraine. Cephalalgia 28:1315-1326

19. Storey JR, Calder CS, Hart DE, Potter DL (2001) Topiramate in migraine prevention: a double-blind, placebo-controlled study. Headache 41:968-975

20. Silvestrini M, Bartolini M, Coccia M, Baruffaldi R, Taffi R, Provinciali L (2003) Topiramate in the treatment of chronic migraine. Cephalalgia 23:820-824

21. Brandes JL, Saper JR, Diamond M, Couch JR, Lewis DW, Schmitt J, Neto W, Schwabe S, Jacobs D (2004) Topiramate for migraine prevention: a randomized controlled trial. JAMA 291:965-973

22. Diener HC, Tfelt-Hansen P, Dahlof C, Lainez MJ, Sandrini G, Wang SJ, Neto W, Vijapurkar U, Doyle A, Jacobs D (2004) Topiramate in migraine prophylaxis-results from a placebo-controlled trial with propranolol as an active control. J Neurol 251:943-950

23. Silberstein SD, Neto W, Schmitt J, Jacobs D (2004) Topiramate in migraine prevention: results of a large controlled trial. Arch Neurol 61:490-495

24. Silberstein SD, Hulihan J, Karim MR, Wu SC, Jordan D, Karvois D, Kamin M (2006) Efficacy and tolerability of topiramate $200 \mathrm{mg} / \mathrm{d}$ in the prevention of migraine with/without aura in adults: a randomized, placebo-controlled, double-blind, 12-week pilot study. Clin Ther 28:1002-1011

25. Silberstein SD, Lipton RB, Dodick DW, Freitag FG, Ramadan N, Mathew N, Brandes JL, Bigal M, Saper J, Ascher S et al (2007) Efficacy and safety of topiramate for the treatment of chronic migraine: a randomized, double-blind, placebo-controlled trial. Headache 47:170-180

26. Diener HC, Bussone G, Van Oene JC, Lahaye M, Schwalen S, Goadsby PJ (2007) Topiramate reduces headache days in chronic migraine: a randomized, double-blind, placebo-controlled study. Cephalalgia 27:814-823

27. Keskinbora K, Aydinli I (2008) A double-blind randomized controlled trial of topiramate and amitriptyline either alone or in combination for the prevention of migraine. Clin Neurol Neurosurg 110:979-984

28. Ashtari F, Shaygannejad V, Akbari M (2008) A double-blind, randomized trial of low-dose topiramate vs propranolol in migraine prophylaxis. Acta Neurol Scand 118:301-305

29. Millan-Guerrero RO, Isais-Millan R, Barreto-Vizcaino S, Gutierrez I, Rivera-Castano L, Trujillo-Hernandez B, Baltazar LM (2008) Subcutaneous histamine versus topiramate in migraine prophylaxis: a double-blind study. Eur Neurol 59:237-242

30. Dodick DW, Freitag F, Banks J, Saper J, Xiang J, Rupnow M, Biondi D, Greenberg SJ, Hulihan J (2009) Topiramate versus amitriptyline in migraine prevention: a 26 -week, multicenter, randomized, double-blind, double-dummy, parallel-group noninferiority trial in adult migraineurs. Clin Ther 31:542-559 
31. Adelman J, Freitag FG, Lainez M, Shi Y, Ascher S, Mao L, Greenberg S, Hulihan J (2008) Analysis of safety and tolerability data obtained from over 1,500 patients receiving topiramate for migraine prevention in controlled trials. Pain Med 9:175-185

32. White HS (2005) Molecular pharmacology of topiramate: managing seizures and preventing migraine. Headache 45(Suppl 1): S48-S56

33. Calabresi P, Galletti F, Rossi C, Sarchielli P, Cupini LM (2007) Antiepileptic drugs in migraine: from clinical aspects to cellular mechanisms. Trends Pharmacol Sci 28:188-195

34. Azimova YE, Tabeeva GR (2007) Prophylactic treatment of migraine with topamax: long-term results. Neurosci Behav Physiol 37:125-127

35. Artemenko AR, Kurenkov AL, Filatova EG, Nikitin SS, Kaube H, Katsarava Z (2008) Effects of topiramate on migraine frequency and cortical excitability in patients with frequent migraine. Cephalalgia 28:203-208

36. D'Amico D, Grazzi L, Bussone G (2006) Topiramate in the prevention of migraine: a review of its efficacy, tolerability, and acceptability. Neuropsychiatr Dis Treat 2:261-267

37. Di Trapani G, Mei D, Marra C, Mazza S, Capuano A (2000) Gabapentin in the prophylaxis of migraine: a double-blind randomized placebo-controlled study. Clin Ther 151:145-148

38. Mathew NT, Rapoport A, Saper J, Magnus L, Klapper J, Ramadan N, Stacey B, Tepper S (2001) Efficacy of gabapentin in migraine prophylaxis. Headache 41:119-128

39. Jimenez-Hernandez MD, Torrecillas Narvaez MD, Friera Acebal G (2002) Effectiveness and safety of gabapentin in the preventive treatment of migraine. Rev Neurol 35:603-606

40. Steiner TJ, Findley LJ, Yuen AW (1997) Lamotrigine versus placebo in the prophylaxis of migraine with and without aura. Cephalalgia 17:109-112

41. Pascual J, Caminero AB, Mateos V, Roig C, Leira R, GarciaMonco C, Lainez MJ (2004) Preventing disturbing migraine aura with lamotrigine: an open study. Headache 44:1024-1028

42. Lampl C, Katsarava Z, Diener HC, Limmroth V (2005) Lamotrigine reduces migraine aura and migraine attacks in patients with migraine with aura. J Neurol Neurosurg Psychiatry 76:1730-1732

43. d'Onofrio F, Cologno D, Petretta V, Casucci G, Bussone G (2007) Basilar-type migraine responsive to lamotrigine: three case reports. Neurol Sci 28(Suppl 2):S239-S241

44. Silberstein S, Saper J, Berenson F, Somogyi M, McCague K, D'Souza J (2008) Oxcarbazepine in migraine headache: a doubleblind, randomized, placebo-controlled study. Neurology 70:548-555

45. Drake ME Jr, Greathouse NI, Renner JB, Armentbright AD (2004) Open-label zonisamide for refractory migraine. Clin Neuropharmacol 27:278-280

46. Ashkenazi A, Benlifer A, Korenblit J, Silberstein SD (2006) Zonisamide for migraine prophylaxis in refractory patients. Cephalalgia 26:1199-1202

47. Bermejo PE, Dorado R (2009) Zonisamide for migraine prophylaxis in patients refractory to topiramate. Clin Neuropharmacol 32(2):103-106

48. Pakalnis A, Kring D (2006) Zonisamide prophylaxis in refractory pediatric headache. Headache 46:804-807

49. Miller GS (2004) Efficacy and safety of levetiracetam in pediatric migraine. Headache 44:238-243

50. Pakalnis A, Kring D, Meier L (2007) Levetiracetam prophylaxis in pediatric migraine - an open-label study. Headache 47:427-430

51. Brighina F, Palermo A, Aloisio A, Francolini M, Giglia G, Fierro B (2006) Levetiracetam in the prophylaxis of migraine with aura: a 6-month open-label study. Clin Neuropharmacol 29:338-342

52. Read SJ, Hirst WD, Upton N, Parsons AA (2001) Cortical spreading depression produces increased cGMP levels in cortex and brain stem that is inhibited by tonabersat (SB-220453) but not sumatriptan. Brain Res 891:69-77
53. Read SJ, Smith MI, Hunter AJ, Upton N, Parsons AA (2000) SB-220453, a potential novel antimigraine agent, inhibits nitric oxide release following induction of cortical spreading depression in the anaesthetized cat. Cephalalgia 20:92-99

54. MaassenVanDenBrink A, van den Broek RW, de Vries R, Upton N, Parsons AA, Saxena PR (2000) The potential anti-migraine compound SB-220453 does not contract human isolated blood vessels or myocardium; a comparison with sumatriptan. Cephalalgia 20:538-545

55. Parsons AA, Bingham S, Raval P, Read S, Thompson M, Upton N (2001) Tonabersat (SB-220453) a novel benzopyran with anticonvulsant properties attenuates trigeminal nerve-induced neurovascular reflexes. Br J Pharmacol 132:1549-1557

56. Tvedskov JF, Iversen HK, Olesen J (2004) A double-blind study of SB-220453 (Tonerbasat) in the glyceryltrinitrate (GTN) model of migraine. Cephalalgia 24:875-882

57. Goadsby PJ, Ferrari MD, Csanyi A, Olesen J, Mills JG (2009) Randomized, double-blind, placebo-controlled, proof-of-concept study of the cortical spreading depression inhibiting agent tonabersat in migraine prophylaxis. Cephalalgia 29:742-750

58. Hauge AW, Asghar MS, Schytz HW, Christensen K, Olesen J (2009) Effects of tonabersat on migraine with aura: a randomised, double-blind, placebo-controlled crossover study. Lancet Neurol 8:718-723

59. Dessy C, Saliez J, Ghisdal P, Daneau G, Lobysheva II, Frerart F, Belge C, Jnaoui K, Noirhomme P, Feron O et al (2005) Endothelial beta3-adrenoreceptors mediate nitric oxide-dependent vasorelaxation of coronary microvessels in response to the thirdgeneration beta-blocker nebivolol. Circulation 112:1198-1205

60. Schellenberg R, Lichtenthal A, Wohling H, Graf C, Brixius K (2008) Nebivolol and metoprolol for treating migraine: an advance on beta-blocker treatment? Headache 48:118-125

61. Schrader H, Stovner LJ, Helde G, Sand T, Bovim G (2001) Prophylactic treatment of migraine with angiotensin converting enzyme inhibitor (lisinopril): randomised, placebo controlled, crossover study. BMJ (Clinical researched) 322:19-22

62. Tronvik E, Stovner LJ, Helde G, Sand T, Bovim G (2003) Prophylactic treatment of migraine with an angiotensin II receptor blocker: a randomized controlled trial. JAMA 289:65-69

63. Diener HC, Gendolla A, Feuersenger A, Evers S, Straube A, Schumacher Het al (2009) Telmisartan in migraine prophylaxis: a randomized, placebo-controlled trial. Cephalalgia 29(9):921-927

64. Stark RJ, Stark CD (2008) Migraine prophylaxis. Med J Aust 189:283-288

65. Sicuteri F (1981) Enkephalinase inhibition relieves pain syndromes of central dysnociception (migraine and related headache). Cephalalgia 1:229-232

66. Bender WI (1995) ACE inhibitors for prophylaxis of migraine headaches. Headache 35:470-471

67. Schuh-Hofer S, Flach U, Meisel A, Israel H, Reuter U, Arnold G (2007) Efficacy of lisinopril in migraine prophylaxis - an open label study. Eur J Neurol 14:701-703

68. Owada K (2004) Efficacy of candesartan in the treatment of migraine in hypertensive patients. Hypertens Res 27:441-446

69. Rahimtoola H, Buurma H, Tijssen CC, Leufkens HG, Egberts AC (2004) Reduction in the therapeutic intensity of abortive migraine drug use during ACE inhibition therapy - a pilot study. Pharmacoepidemiol Drug Saf 13:41-47

70. Etminan M, Levine MA, Tomlinson G, Rochon PA (2002) Efficacy of angiotensin II receptor antagonists in preventing headache: a systematic overview and meta-analysis. Am J Med 112:642-646

71. Saavedra JM, Benicky J, Zhou J (2006) Angiotensin II: multitasking in the brain. J Hypertens Suppl 24:S131-S137

72. Imboden H, Patil J, Nussberger J, Nicoud F, Hess B, Ahmed N, Schaffner T, Wellner M, Muller D, Inagami T et al (2009) 
Endogenous angiotensinergic system in neurons of rat and human trigeminal ganglia. Regul Pept 154:23-31

73. Ramadan NM, Schultz LL, Gilkey SJ (1997) Migraine prophylactic drugs: proof of efficacy, utilization and cost. Cephalalgia 17:73-80

74. Moja PL, Cusi C, Sterzi RR, Canepari C (2005) Selective serotonin re-uptake inhibitors (SSRIs) for preventing migraine and tension-type headaches. Cochrane Database Syst Rev 20:CD002919

75. Ozyalcin SN, Talu GK, Kiziltan E, Yucel B, Ertas M, Disci R (2005) The efficacy and safety of venlafaxine in the prophylaxis of migraine. Headache 45:144-152

76. Taylor AP, Adelman JU, Freeman MC (2007) Efficacy of duloxetine as a migraine preventive medication: possible predictors of response in a retrospective chart review. Headache 47:1200-1203

77. Dahlof CG, Hargreaves RJ (1998) Pathophysiology and pharmacology of migraine. Is there a place for antiemetics in future treatment strategies? Cephalalgia 18:593-604

78. Honkaniemi J, Liimatainen S, Rainesalo S, Sulavuori S (2006) Haloperidol in the acute treatment of migraine: a randomized, double-blind, placebo-controlled study. Headache 46:781-787

79. Bigal ME, Bordini CA, Speciali JG (2002) Intravenous chlorpromazine in the emergency department treatment of migraines: a randomized controlled trial. J Emerg Med 23:141-148

80. Silberstein SD, Young WB, Mendizabal JE, Rothrock JF, Alam AS (2003) Acute migraine treatment with droperidol: a randomized, double-blind, placebo-controlled trial. Neurology 60:315-321

81. Silberstein SD, Peres MF, Hopkins MM, Shechter AL, Young WB, Rozen TD (2002) Olanzapine in the treatment of refractory migraine and chronic daily headache. Headache 42:515-518

82. Edvinsson L (2008) CGRP-receptor antagonism in migraine treatment. Lancet 372:2089-2090

83. Tvedskov JF, Lipka K, Ashina M, Iversen HK, Schifter S, Olesen J (2005) No increase of calcitonin gene-related peptide in jugular blood during migraine. Ann Neurol 58:561-568

84. Lassen LH, Haderslev PA, Jacobsen VB, Iversen HK, Sperling $\mathrm{B}$, Olesen J (2002) CGRP may play a causative role in migraine. Cephalalgia 22:54-61

85. Link AS, Kuris A, Edvinsson L (2008) Treatment of migraine attacks based on the interaction with the trigemino-cerebrovascular system. J Headache Pain 9:5-12

86. Olesen J, Diener HC, Husstedt IW, Goadsby PJ, Hall D, Meier U, Pollentier S, Lesko LM (2004) Calcitonin gene-related peptide receptor antagonist BIBN 4096 BS for the acute treatment of migraine. N Engl J Med 350:1104-1110

87. Ho TW, Ferrari MD, Dodick DW, Galet V, Kost J, Fan X, Leibensperger H, Froman S, Assaid C, Lines C et al (2008) Efficacy and tolerability of MK-0974 (telcagepant), a new oral antagonist of calcitonin gene-related peptide receptor, compared with zolmitriptan for acute migraine: a randomised, placebocontrolled, parallel-treatment trial. Lancet 372:2115-2123

88. Ho TW, Mannix LK, Fan X, Assaid C, Furtek C, Jones CJ, Lines CR, Rapoport AM (2008) Randomized controlled trial of an oral CGRP receptor antagonist, MK-0974, in acute treatment of migraine. Neurology 70:1304-1312

89. Juhl L, Edvinsson L, Olesen J, Jansen-Olesen I (2007) Effect of two novel CGRP-binding compounds in a closed cranial window rat model. Eur J Pharmacol 567:117-124

90. Levy MJ, Matharu MS, Bhola R, Meeran K, Goadsby PJ (2005) Octreotide is not effective in the acute treatment of migraine. Cephalalgia 25:48-55

91. Olesen J (2008) The role of nitric oxide (NO) in migraine, tensiontype headache and cluster headache. Pharmacol Ther 120:157-171

92. Lassen LH, Ashina M, Christiansen I, Ulrich V, Grover R, Donaldson J, Olesen J (1998) Nitric oxide synthase inhibition: a new principle in the treatment of migraine attacks. Cephalalgia 18:27-32
93. van der Kuy PH, Merkus FW, Lohman JJ, ter Berg JW, Hooymans PM (2002) Hydroxocobalamin, a nitric oxide scavenger, in the prophylaxis of migraine: an open, pilot study. Cephalalgia 22:513-519

94. McCall RB, Huff R, Chio CL, TenBrink R, Bergh CL, Ennis MD, Ghazal NB, Hoffman RL, Meisheri K, Higdon NR et al (2002) Preclinical studies characterizing the anti-migraine and cardiovascular effects of the selective 5-HT1D receptor agonist PNU-142633. Cephalalgia 22:799-806

95. Gomez-Mancilla B, Cutler NR, Leibowitz MT, Spierings EL, Klapper JA, Diamond S, Goldstein J, Smith T, Couch JR, Fleishaker J et al (2001) Safety and efficacy of PNU-142633, a selective 5-HT1D agonist, in patients with acute migraine. Cephalalgia 21:727-732

96. Goldstein DJ, Roon KI, Offen WW, Ramadan NM, Phebus LA, Johnson KW, Schaus JM, Ferrari MD (2001) Selective seratonin $1 \mathrm{~F}(5-\mathrm{HT}(1 \mathrm{~F}))$ receptor agonist LY334370 for acute migraine: a randomised controlled trial. Lancet 358:1230-1234

97. Ramadan NM, Skljarevski V, Phebus LA, Johnson KW (2003) 5-HT1F receptor agonists in acute migraine treatment: a hypothesis. Cephalalgia 23:776-785

98. Saper JR, Silberstein S, Dodick D, Rapoport A (2006) DHE in the pharmacotherapy of migraine: potential for a larger role. Headache 46(Suppl 4):S212-S220

99. Shrewsbury SB, Cook RO, Taylor G, Edwards C, Ramadan NM (2008) Safety and pharmacokinetics of dihydroergotamine mesylate administered via a Novel (Tempo) inhaler. Headache 48:355-367

100. Shrewsbury SB, Kori SH, Miller SD, Pedinoff A, Weinstein S (2008) Randomized, double-blind, placebo-controlled study of the safety, tolerability and pharmacokinetics of MAP0004 (orally-inhaled DHE) in adult asthmatics. Curr Med Res Opin 24:1977-1985

101. Aurora SK, Rozen TD, Kori SH, Shrewsbury SB (2009) A randomized, double blind, placebo-controlled study of MAP0004 in adult patients with migraine. Headache 49(6):826-837

102. Kaube H, Herzog J, Kaufer T, Dichgans M, Diener HC (2000) Aura in some patients with familial hemiplegic migraine can be stopped by intranasal ketamine. Neurology 55:139-141

103. Sang CN, Ramadan NM, Wallihan RG, Chappell AS, Freitag FG, Smith TR, Silberstein SD, Johnson KW, Phebus LA, Bleakman D et al (2004) LY293558, a novel AMPA/GluR5 antagonist, is efficacious and well-tolerated in acute migraine. Cephalalgia 24:596-602

104. Szallasi A, Cortright DN, Blum CA, Eid SR (2007) The vanilloid receptor TRPV1: 10 years from channel cloning to antagonist proof-of-concept. Nat Rev Drug Discov 6:357-372

105. Knotkova H, Pappagallo M, Szallasi A (2008) Capsaicin (TRPV1 Agonist) therapy for pain relief: farewell or revival? Clin J Pain 24:142-154

106. Funk CD, FitzGerald GA (2007) COX-2 inhibitors and cardiovascular risk. J Cardiovasc Pharmacol 50:470-479

107. Silberstein S, Tepper S, Brandes J, Diamond M, Goldstein J, Winner P, Venkatraman S, Vrijens F, Malbecq W, Lines C et al (2004) Randomized, placebo-controlled trial of rofecoxib in the acute treatment of migraine. Neurology 62:1552-1557

108. Kudrow D, Thomas HM, Ruoff G, Ishkanian G, Sands G, Le VH, Brown MT (2005) Valdecoxib for treatment of a single, acute, moderate to severe migraine headache. Headache 45:1151-1162

109. Loo CY, Tan HJ, Teh HS, Raymond AA (2007) Randomised, open label, controlled trial of celecoxib in the treatment of acute migraine. Singapore Med J 48:834-839

110. Vecsei L, Gallacchi G, Sagi I, Semjen J, Tajti J, Szok D, Muller M, Vadass P, Kerekgyarto M (2007) Diclofenac epolamine is effective in the treatment of acute migraine attacks. A randomized, crossover, double blind, placebo-controlled, clinical study. Cephalalgia 27:29-34 
111. Peroutka SJ, Lyon JA, Swarbrick J, Lipton RB, Kolodner K, Goldstein J (2004) Efficacy of diclofenac sodium softgel $100 \mathrm{mg}$ with or without caffeine $100 \mathrm{mg}$ in migraine without aura: a randomized, double-blind, crossover study. Headache 44:136-141

112. Maubach KA, Davis RJ, Clark DE, Fenton G, Lockey PM, Clark KL et al (2009) BGC20-1531, a novel, potent and selective prostanoid EP receptor antagonist: a putative new treatment for migraine headache. Br J Pharmacol 156(2):316-327

113. Lin CR, Amaya F, Barrett L, Wang H, Takada J, Samad TA, Woolf CJ (2006) Prostaglandin E2 receptor EP4 contributes to inflammatory pain hypersensitivity. J Pharmacol Exp Ther 319:1096-1103

114. Nakao K, Murase A, Ohshiro H, Okumura T, Taniguchi K, Murata Y, Masuda M, Kato T, Okumura Y, Takada J (2007) CJ-023, 423, a novel, potent and selective prostaglandin EP4 receptor antagonist with antihyperalgesic properties. J Pharmacol Exp Ther 322:686-694

115. Couch JR, Zagami AS (2005) Status migrainosus. In: Olesen J, Goadsby PJ, Ramadan NM, Tfelt-Hansen P, Welch KMA (eds) The headaches, 3rd edn. Williams \& Wilkins, Lippincott, pp 595-598

116. Colman I, Friedman BW, Brown MD, Innes GD, Grafstein E, Roberts TE, Rowe BH (2008) Parenteral dexamethasone for acute severe migraine headache: meta-analysis of randomised controlled trials for preventing recurrence. BMJ 336:1359-1361

117. Friedman BW, Greenwald P, Bania TC, Esses D, Hochberg M, Solorzano C, Corbo J, Chu J, Chew E, Cheung P et al (2007) Randomized trial of IV dexamethasone for acute migraine in the emergency department. Neurology 69:2038-2044

118. Kelly AM (2000) Migraine: pharmacotherapy in the emergency department. West J Med 173:189-193

119. Lipton RB, Baggish JS, Stewart WF, Codispoti JR, Fu M (2000) Efficacy and safety of acetaminophen in the treatment of migraine: results of a randomized, double-blind, placebo-controlled, population-based study. Arch Intern Med 160:34863492

120. Diener HC, Pfaffenrath V, Schnitker J, Friede M, Henneicke-von Zepelin HH (2005) Efficacy and safety of $6.25 \mathrm{mg}$ t.i.d. feverfew CO2-extract (MIG-99) in migraine prevention-a randomized, double-blind, multicentre, placebo-controlled study. Cephalalgia 25:1031-1041

121. Diener HC, Rahlfs VW, Danesch U (2004) The first placebocontrolled trial of a special butterbur root extract for the prevention of migraine: reanalysis of efficacy criteria. Eur Neurol 51:89-97

122. Lipton RB, Gobel H, Einhaupl KM, Wilks K, Mauskop A (2004) Petasites hybridus root (butterbur) is an effective preventive treatment for migraine. Neurology 63:2240-2244

123. Gupta VK (2006) Botulinum toxin—a treatment for migraine? A systematic review. Pain Med 7:386-394

124. Silberstein S, Mathew N, Saper J, Jenkins S (2000) Botulinum toxin type A as a migraine preventive treatment. For the BOTOX Migraine Clinical Research Group. Headache 40:445-450

125. Evers S, Vollmer-Haase J, Schwaag S, Rahmann A, Husstedt IW, Frese A (2004) Botulinum toxin A in the prophylactic treatment of migraine-a randomized, double-blind, placebocontrolled study. Cephalalgia 24:838-843

126. Aurora SK, Gawel M, Brandes JL, Pokta S, Vandenburgh AM (2007) Botulinum toxin type a prophylactic treatment of episodic migraine: a randomized, double-blind, placebo-controlled exploratory study. Headache 47:486-499

127. Elkind AH, O'Carroll P, Blumenfeld A, DeGryse R, Dimitrova $\mathrm{R}$ (2006) A series of three sequential, randomized, controlled studies of repeated treatments with botulinum toxin type A for migraine prophylaxis. J Pain 7:688-696
128. Relja M, Poole AC, Schoenen J, Pascual J, Lei X, Thompson C (2007) A multicentre, double-blind, randomized, placebo-controlled, parallel group study of multiple treatments of botulinum toxin type A (BoNTA) for the prophylaxis of episodic migraine headaches. Cephalalgia 27:492-503

129. Cady R, Schreiber C (2008) Botulinum toxin type A as migraine preventive treatment in patients previously failing oral prophylactic treatment due to compliance issues. Headache 48:900-913

130. Evers S (2006) Status on the use of botulinum toxin for headache disorders. Curr Opin Neurol 19:310-315

131. Schulte-Mattler WJ, Leinisch E (2008) Evidence based medicine on the use of botulinum toxin for headache disorders. $\mathrm{J}$ Neural Transm 115:647-651

132. Naumann M, So Y, Argoff CE, Childers MK, Dykstra DD, Gronseth GS, Jabbari B, Kaufmann HC, Schurch B, Silberstein SD et al (2008) Assessment: Botulinum neurotoxin in the treatment of autonomic disorders and pain (an evidence-based review): report of the Therapeutics and Technology Assessment Subcommittee of the American Academy of Neurology. Neurology 70:1707-1714

133. Mauskop A, Mathew N (2009) Assessment: botulinum neurotoxin in the treatment of autonomic disorders and pain (an evidence-based review): report of the therapeutics and technology assessment subcommittee of the american academy of neurology. Neurology 72:1367 (author reply 1367-1368)

134. Smith TR, Sunshine A, Stark SR, Littlefield DE, Spruill SE, Alexander WJ (2005) Sumatriptan and naproxen sodium for the acute treatment of migraine. Headache 45:983-991

135. Brandes JL, Kudrow D, Stark SR, O'Carroll CP, Adelman JU, O'Donnell FJ, Alexander WJ, Spruill SE, Barrett PS, Lener SE (2007) Sumatriptan-naproxen for acute treatment of migraine: a randomized trial. JAMA 297:1443-1454

136. Winner P, Cady RK, Ruoff GE, Frishberg BM, Alexander WJ, Zhang Y, Kori SH, Lener SE (2007) Twelve-month tolerability and safety of sumatriptan-naproxen sodium for the treatment of acute migraine. Mayo Clin Proc 82:61-68

137. Di Monda V, Nicolodi M, Aloisio A, Del Bianco P, Fonzari M, Grazioli I, Uslenghi C, Vecchiet L, Sicuteri F (2003) Efficacy of a fixed combination of indomethacin, prochlorperazine, and caffeine versus sumatriptan in acute treatment of multiple migraine attacks: a multicenter, randomized, crossover trial. Headache 43:835-844

138. Sandrini G, Cerbo R, Del Bene E, Ferrari A, Genco S, Grazioli I, Martelletti P, Nappi G, Pinessi L, Sarchielli P et al (2007) Efficacy of dosing and re-dosing of two oral fixed combinations of indomethacin, prochlorperazine and caffeine compared with oral sumatriptan in the acute treatment of multiple migraine attacks: a double-blind, double-dummy, randomised, parallel group, multicentre study. Int J Clin Pract 61:1256-1269

139. Goldstein J, Silberstein SD, Saper JR, Elkind AH, Smith TR, Gallagher RM, Battikha JP, Hoffman H, Baggish J (2005) Acetaminophen, aspirin, and caffeine versus sumatriptan succinate in the early treatment of migraine: results from the ASSET trial. Headache 45:973-982

140. Silberstein SD, Freitag FG, Rozen TD, Kudrow DB, Hewitt DJ, Jordan DM, Fisher AC, Rosenthal NR (2005) Tramadol/acetaminophen for the treatment of acute migraine pain: findings of a randomized, placebo-controlled trial. Headache 45:1317-1327

141. Maizels M, Blumenfeld A, Burchette R (2004) A combination of riboflavin, magnesium, and feverfew for migraine prophylaxis: a randomized trial. Headache 44:885-890

142. Diener HC, Agosti R, Allais G, Bergmans P, Bussone G, Davies B, Ertas M, Lanteri-Minet M, Reuter U, Del Rio MS et al (2007) Cessation versus continuation of 6-month migraine preventive therapy with topiramate (PROMPT): a randomised, doubleblind, placebo-controlled trial. Lancet Neurol 6:1054-1062 